\title{
EFFECTS OF SUBZERO TREATMENTS ON THE MECHANICAL PROPERTIES OF THE SAE 4140 STEEL
}

\author{
VPLIV GLOBOKE PODHLADITVE SAE JEKLA 4140 NA NJEGOVE \\ MEHANSKE LASTNOSTI
}

\author{
İsmail Sahin ${ }^{*}$, Gürhan Höke², Henifi Çinici ${ }^{3}$, Tayfun Findık ${ }^{3}$, Haluk Koralay ${ }^{4}$, \\ Uğur Arabaci ${ }^{3}$ \\ ${ }^{1}$ Gazi University, Department of Industrial Design Engineering, 06550 Ankara, Turkey \\ 2Turk Traktor Company, Anadolu Avenue No. 52-52A, 06560 Ankara, Turkey \\ ${ }^{3}$ Gazi University, Department of Metallurgical and Materials Engineering, 06550 Ankara, Turkey \\ ${ }^{4}$ Gazi University, Department of Physic, 06550 Ankara, Turkey \\ Prejem rokopisa - received: 2018-07-04; sprejem za objavo - accepted for publication: 2019-01-17
}

doi:10.17222/mit.2018.135

\begin{abstract}
In this study, effects of holding in liquid nitrogen and cryogenic methods applied onto the SAE 4140 steel were empirically investigated. In this context, austempering, holding in liquid nitrogen, the conventional cryogenic process and tempering processes were applied in different orders and combinations. The temperature of the samples to be tempered in liquid nitrogen was decreased from room temperature to $-196^{\circ} \mathrm{C}$ at the average rate of $1.6^{\circ} \mathrm{C} / \mathrm{min}$ and held at this temperature for $24 \mathrm{~h}$. The temperature of the samples to undergo the traditional cryogenic process was decreased from room temperature to $-140{ }^{\circ} \mathrm{C}$ at a constant rate of $2{ }^{\circ} \mathrm{C} / \mathrm{min}$ and held at this temperature for $24 \mathrm{~h}$. After a microhardness analysis and tensile tests, it was observed that the toughness was increased without the hardness being changed during both cooling processes carried out after austempering processes. The most obvious improvement in terms of toughness was observed on the samples, to which austempering was applied, exibiting an increase of $32.83 \%$, followed by the samples undergoing the cryogenic process and, lastly, the ones undergoing the tempering process. The largest increase in the tensile strength also occurred in the samples subjected to austempering, exhibiting a $66 \mathrm{~N} / \mathrm{mm}^{2}$ improvement. In terms of the properties investigated during this study, it was seen that the process of holding steel in liquid nitrogen could consitute an alternative to the cryogenic process using different rates.

Keywords: SAE 4140, cryogenic process, liquid nitrogen, XRD (X-ray diffraction)
\end{abstract}

V študiji avtorji opisujejo empirično raziskavo vpliva zadrževanja jekla SAE $4140 \mathrm{v}$ tekočem dušiku in raziskavo kriogenih tehnik. V zvezi s tem so izvajali različne procese, kot so austempering, zadrževanje v tekočem dušiku, konvencionalni kriogeni procesi in popuščanje $\mathrm{v}$ različnem redosledu. Vzorce jekla so po kaljenju ohlajali v tekočem dušiku s sobne temperature na temperaturo $-196{ }^{\circ} \mathrm{C}$ s povprečno hitrostjo $1,6{ }^{\circ} \mathrm{C} / \mathrm{min}$ in jih na končni temperaturi podhladitve zadrževali 24 ur. Vzorce, ki so jih obdelali po konvencionalnem kriogenem postopku so ohlajali s sobne temperature na $-140{ }^{\circ} \mathrm{C} \mathrm{s}$ konstantno hitrostjo $2{ }^{\circ} \mathrm{C} / \mathrm{min}$ in jih na temperaturi podhladitve ravnotako zadrževali 24 ur. Po teh krio- obdelavah so izvedli natezne preizkuse in meritve mikrotrdote. Ugotovili so, da je v vseh izvedenih primerih podhlajanja, katerim je sledil še postopek austemperinga,narasla žilavostne da bi se pri tem bistveno spremenila trdota jekla. Najbolj očitna-32,83 \%- izboljšava je bila vidna pri vzorcih pri katerih je bil izveden austempering postopek, ki je sledil kriogenemu procesu in na katerih je bil izveden tudi postopek popuščanja. Ti vzorci so imeli tudi najvišjo natezno trdnost z izboljšanjem za $66 \mathrm{~N} / \mathrm{mm}^{2}$. Glede na izvedene raziskave avtorji ugotavljajo, da proces zadrževanja v tekočem dušiku lahko predstavlja alternativo konvencionalnim kriogenim postopkom.

Ključne besede: SAE jeklo 4140, proces podhladitve, tekoči dušik, rentgenska difrakcija (XRD)

\section{INTRODUCTION}

Materials for manufacturing mechanical systems are used under difficult conditions such as excessive load and high speed. ${ }^{1}$ The selection of the materials used in the making of machine parts and the heat treatment applied to these materials are directly related to the economic life of a machine. ${ }^{2-4}$ Through a cryogenic process, which is a type of heat treatment that can be applied to steel, requiring low temperatures, it is possible to turn the whole of the material's structure into martensite and increase the toughness. ${ }^{5}$

The SAE 4140 (42CrMo4) steel, having a wide area of use in the machine-manufacturing industry, is a type of steel with a high hardenability thanks to the alloys it

*Corresponding author's e-mail:

isahin@gazi.edu.tr contains and it can demonstrate high toughness under certain loads following the austempering process. ${ }^{6}$ The SAE 4140 steel can provide mechanical properties such as strength, hardness and toughness under suitable heattreatment conditions. ${ }^{7,8}$ The AISI 4100 grade steels are also called low-alloy structural steels, forged steels, medium-carbon steels and alloy steels. These steels are used for crankshafts, axle shafts and sleeves, spline shafts, gear wheels, cold-drawn shafts and rods, machine steels, springs, turbine engines, brake rings and levers of turbo generators, chains and anchors of ships, railway wheels and shafts, starter gears and many other parts.

In the 1950s, tool manufacturers tried the process of immersing and holding tools in liquid nitrogen, which was the starting point of the cryogenic process, a newgeneration heat-treatment method. However, this method resulted in damage to the tools due to thermal shocks. 
Thus, more effective and controlled techniques were developed, including programmable temperature controllers to reduce the likelihood of a thermal shock, a solenoid valve to control the flow of liquid nitrogen, and a thermocouple to display the temperature of the workpiece; thus, cryogenic processing systems used today were formed.

A cyrogenic process, widely used in recent years, is a heat-treatment process applied to strengthen the mechanical properties of materials. A cryogenic process has many application areas from space research to food transportation. ${ }^{9}$ Similarly, it can modify cutting-tool tips, carburization and cementation steels used for gears, HSS steels and AISI 4340 steels by increasing the resistance to cracking, tool life, hardness, resistance to wear and tear and fatigue strength. ${ }^{10-18}$

From the research reported on in the literature, it is seen that the effects of the process of holding steel in liquid nitrogen or cryogenic process on the mechanical properties of the SAE 4140 steel have not been investigated. Any improvement to the SAE 4140 steel, having a wide area of use in the production of important mechanisms in the industry such as rail steel and gears, and transmission mills in particular, would provide significant advantages for industrial applications.

The process of holding in liquid nitrogen aims at simplifying the cryogenic process, turning it into a heattreatment method that is more accessible. Thus, midscale enterprises would be able to organise this process within their organisations with smaller investments and this process would be popularised. With this purpose in mind, the effects of the process of holding in liquid nitrogen (HPLN) and the cryogenic process (CP) on the mechanical properties of the SAE 4140 steel were investigated individually in this study. This is a pioneering study. XRD analyses of the crystallographic structures obtained with the HPLN and CP processes were also made.

\section{MATERIALS AND METHODS}

SAE 4140 steel bars, $12 \mathrm{~mm}$ in diameter and $6 \mathrm{~m}$ in length, were used in the study. The samples taken from these bars were first chemically analysed. In the wake of the analyses, it was noticed that the material was $42 \mathrm{CrMo}_{4}(\mathrm{SAE} 4140)$ and the bars used were of the same batch (Table 1).

Table 1: Chemical compositions of SAE 4140 samples

\begin{tabular}{|c|c|c|c|c|}
\hline Element & $\begin{array}{c}\text { Standard } \\
\text { range }\end{array}$ & Sample 1 & Sample 2 & Sample 3 \\
\hline$\% \mathrm{C}$ & $0.35-0.44$ & 0.445 & 0.442 & 0.444 \\
\hline$\% \mathrm{Si}$ & $0.15-0.35$ & 0.263 & 0.267 & 0.262 \\
\hline$\% \mathrm{Mn}$ & $0.60-0.90$ & 0.802 & 0.807 & 0.801 \\
\hline$\% \mathrm{P}$ & $0.0-0.040$ & 0.017 & 0.015 & 0.017 \\
\hline$\% \mathrm{~S}$ & $0.0-0.040$ & 0.026 & 0.024 & 0.026 \\
\hline$\% \mathrm{Cr}$ & $0.8-1.10$ & 0.934 & 0.936 & 0.931 \\
\hline$\% \mathrm{Mo}$ & $0.15-0.25$ & 0.194 & 0.193 & 0.193 \\
\hline
\end{tabular}

Following the chemical analysis, the samples were prepared for a microhardness analysis and tensilestrength test on CNC lathes. For the tensile tests, five samples were manufactured for each variant, 40 in total, in line with the TS EN ISO 6892-1 standard. ${ }^{19}$ A Dartec 25-ton-capacity universal tensile test bench was used for the tensile tests. These tests were carried out at room temperature, with a $3-\mathrm{N}$ preload at a speed of $5 \mathrm{~mm} / \mathrm{min}$.

In order to analyse the impacts of the austempering process, the process of holding in liquid nitrogen, the cryogenic process and the tempering process on the mechanical properties of the SAE 4140 steel, eight different variants were produced in each step. These variants are given in Table 2.

For the austempering process, the samples were held at $850{ }^{\circ} \mathrm{C}$ for $185 \mathrm{~min}$ and subjected to a hardening process cooling them down at $80{ }^{\circ} \mathrm{C}$ in oil. After the hardening process, the tempering process was applied at $230{ }^{\circ} \mathrm{C}$ for $60 \mathrm{~min}$.

During the experiments conducted as part of the study, a cryogenic-process system based on PLC controlled direct cooling was used. The temperature of Variants 3, 6 and 8 was reduced from ambient temperature to $-140{ }^{\circ} \mathrm{C}$ at an average speed of $2{ }^{\circ} \mathrm{C} / \mathrm{min}$ to apply the cryogenic process and they were kept at that temperature for $24 \mathrm{~h}$. After $24 \mathrm{~h}$, the temperature was allowed to rise to ambient temperature again at an average speed of $2{ }^{\circ} \mathrm{C} / \mathrm{min}$. During the process of holding in liquid nitrogen, the cooling period of the samples was recorded in 30-sec intervals by means of a FLUKE 51-II model thermometer and FLUKE T-type thermocouple.

Table 2: Heat-treatment methods applied and variants produced

\begin{tabular}{|c|c|c|c|c|c|}
\hline & $\begin{array}{c}\text { Raw } \\
\text { (R) }\end{array}$ & $\begin{array}{c}\text { Austem- } \\
\text { pering } \\
\text { (A) }\end{array}$ & $\begin{array}{c}\text { Process of } \\
\text { holding in } \\
\text { liquid nitrogen } \\
\text { (HPLN) }\end{array}$ & $\begin{array}{c}\text { Cryogenic } \\
\text { process } \\
\text { (CP) }\end{array}$ & $\begin{array}{c}\text { Tem- } \\
\text { pering } \\
\text { (TE) }\end{array}$ \\
\hline Variant 1 & $\checkmark$ & & & & \\
\hline Variant 2 & & & $\checkmark$ & & \\
\hline Variant 3 & & & & $\checkmark$ & \\
\hline Variant 4 & & $\checkmark$ & & & \\
\hline Variant 5 & & $\checkmark$ & $\checkmark$ & & \\
\hline Variant 6 & & $\checkmark$ & & $\checkmark$ & \\
\hline Variant 7 & & $\checkmark$ & $\checkmark$ & & $\checkmark$ \\
\hline Variant 8 & & $\checkmark$ & & $\checkmark$ & $\checkmark$ \\
\hline
\end{tabular}

The temperature of Variants 2, 5 and 7 was reduced from ambient temperature to $-196{ }^{\circ} \mathrm{C}$ at an average speed of $1.5^{\circ} \mathrm{C} / \mathrm{min}$ to apply the process of holding in liquid nitrogen and the samples were kept at this temperature for $24 \mathrm{~h}$. At the end of $24 \mathrm{~h}$, the temperature was allowed to rise to ambient temperature again at the average speed of $1.5^{\circ} \mathrm{C} / \mathrm{min}$.

Microhardness measurements were made on a DuraScan computer-controlled Vickers-microhardness measuring device. The measurements were made in inter- 
İ. SAHIN et al.: EFFECTS OF SUBZERO TREATMENTS ON THE MECHANICAL PROPERTIES ...

Table 3: Microhardness data (R: raw, HPLN: holding process in liquid nitrogen, CP: cryogenic process, A: austempering, TE: tempering)

\begin{tabular}{|c|c|c|c|c|c|c|c|c|}
\hline $\begin{array}{c}\text { Microhardness } \\
\text { N/mm }\end{array}$ & $\begin{array}{c}\text { Var 1: } \\
\text { R }\end{array}$ & $\begin{array}{c}\text { Var 2: } \\
\text { HPLN }\end{array}$ & $\begin{array}{c}\text { Var 3: } \\
\text { CP }\end{array}$ & $\begin{array}{c}\text { Var 4: } \\
\text { A }\end{array}$ & $\begin{array}{c}\text { Var 5: } \\
\text { A+HPLN }\end{array}$ & $\begin{array}{c}\text { Var 6: } \\
\text { A+CP }\end{array}$ & $\begin{array}{c}\text { Var 7: } \\
\text { A+HPLN+TE }\end{array}$ & $\begin{array}{c}\text { Var 8: } \\
\text { A+CP+TE }\end{array}$ \\
\hline Average & 334 & 339 & 334 & 583 & 589 & 587 & 588 & 600 \\
\hline
\end{tabular}

vals using $1-\mathrm{kg}$ loads and a dimond, square-pyramid tip with an apex angle of $136^{\circ}$.

XRD analyses of the variants were made using radiation $\mathrm{Cu}-K_{\alpha}(\lambda=1.5418 \mathrm{~nm})$ on a computer-controlled, Broker D8 advance-model powder diffractometer. The measurements were taken at a scanning speed of $2 \% \mathrm{~min}$ and at intervals of $2 \theta=10^{\circ}$ to $90^{\circ}$. The analyses of the peaks obtained from these patterns were compared to the data of the International Centre for Diffraction Data (ICDD).

\section{RESULTS AND DISCUSSION}

It was confirmed that when the process of holding in liquid nitrogen or the cryogenic process are applied individually, they have no significant effect on the raw material. Therefore, the values obtained for Variants 1, 2 and 3 relating to the tensile strength, toughness resistance and microhardness did not surpass the initial conditions. The process of holding in liquid nitrogen provided a certain level of improvement of the austempered samples. However, the principal effective results were obtained as a result of the cryogenic process and additional tempering applied after the austempering process. Hence, it was confirmed that the cryogenic process was effective provided that it was applied after the austempering process. Studies reported on in the literature corroborate this phenomena. Researchers remarked that the cryogenic process is a supplementary process applied after the conventional heat treatment and not a process that could replace heat treatment. ${ }^{5,20}$

\subsection{Microhardness measurements}

With the purpose to investigate the effects of the HPLN and CP on the change in the hardness of the SAE 4140 steel, microhardness measurements were made. Using the Vickers-hardness measuring methods, a total of 103 hardness measurements were taken, that is 13 measurements for each sample in the directions and intervals shown in Figure 1. The average hardness values calculated for each variant in each direction are given in Table 3.

It was seen that the HPLN or CP applied onto the raw SAE 4140 steel had no significant effect in terms of hardness. The microhardness values obtained with the purpose to individually analyse the effects of the processes applied onto the samples after austempering were $(589,587,588$ and 600) for Variants 5, 6, 7 and 8, respectively. As it is obvious from the percentages of the changes given, no significant increase was noticed for the variants, apart from Variant 8 . These obtained values are higher than the hardness value of the SAE 4140 steel, to which no austempering was applied and which cooled down in a furnace, air or oil after the austempering at a temperature of $840{ }^{\circ} \mathrm{C} .{ }^{21,22}$

It is known that the distribution characteristics, dimensions, quantity and inter-particle distances of the austenite and martensite in the structure of steel affect the mechanical properties of the material. The graph from Figure 2 was obtained as a result of the martensite volume ratio analyses conducted in accordance with the ASTM E562-02 standard using the microstructure pictures given in Figure 1. It was confirmed that the residual austenite was converted into martensite in certain ratios in all the samples, onto which the PSLN or CP
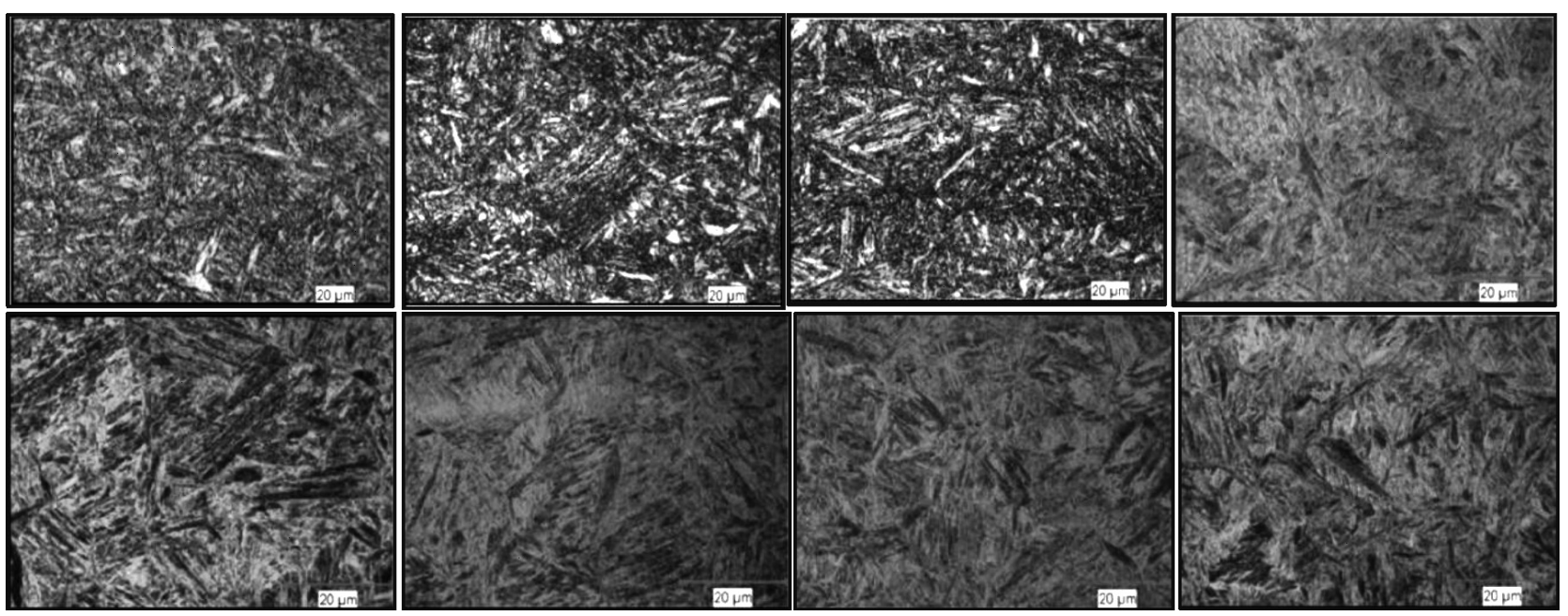

Figure 1: Microstructure images depending on the processes applied to the variants 


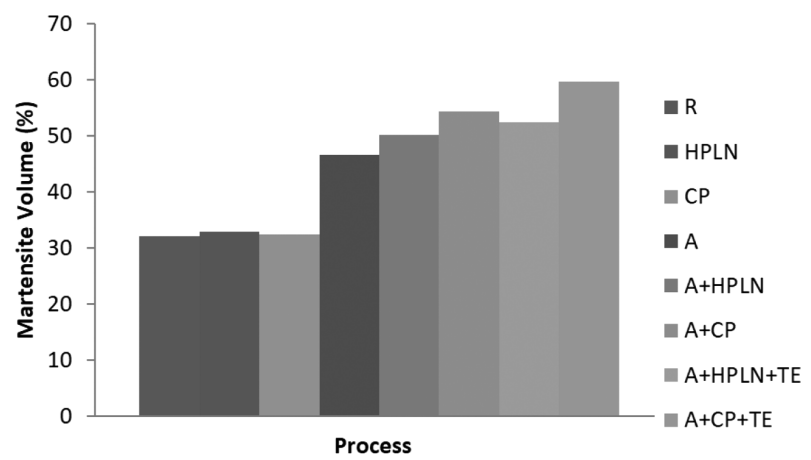

Figure 2: Martensite volume ratio analysis

were applied after austempering. The increase in the volume during the conversion of the residual austenite into martensite causes deformation of the martensite and dislocations in the structure, associated with the deformation resulting from this increase in the volume, form nucleation zones for thin carbides that are deposited by the tempering applied after the cryogenic treatment (Figure 2). ${ }^{23,24}$ At the same time, it is believed that some of the effects caused by the carbide decomposition that occurs during the cryogenic process or the changes in the carburized layer within the structure cause partial changes in the hardness. ${ }^{25}$

It is known that austempering and the increase in the hardness occurring with the tempering applied after austempering increases the wear resistance. ${ }^{26}$ Therefore, it is thought that the HPLN and CP processes applied after austempering and increasing the hardness values would cause the wear resistance to get even higher.

\subsection{Tensile strenght}

It was seen that the tensile strentgh of Variant 1 , which was not treated with the purpose to investigate the effects of the HPLN and CP on the SAE 4140 steel in terms of tensile strength, was relatively higher than the values of Variants 2 and 3. The largest increase in the tensile strength during the studies conducted with the purpose to reveal the effects of the HPLN and CP applied after the austempering was noticed for Variant 8 (Table 4). This was followed by Variant 7.

In order to analyse the effects of the HPLN and CP on the raw SAE 4140 in terms of tensile strength, the percentages of the changes in the tensile strength calcul- ated with reference to Variant 1, onto which no processes were applied, were calculated to be $-0.69 \%$ and $-1.31 \%$ for Variants 2 and 3, respectively. However, to demonstrate the effects of the HPLN and CP for the cases when they were applied after the treatment process, the percentages of the changes in the tensile strength were calculated with reference to Variant 4, which had been treated. The changes in the percentages calculated for Variants 5, 6, 7 and 8 were calculated to be $(-0.32,0.05$, 0.69 and 3.49) \%, respectively. As can be understood from these percentage-change values, the highest increase in the tensile strength occurred for Variant 8 , amounting to $3.49 \%$. This was followed by Variant 7 with $0,69 \%$.

\subsection{Toughness}

Toughness data was calculated with the help of Equation (1) based on the results of the tensile-strength test:

$$
\int_{0}^{\varepsilon_{k}} \sigma \cdot \mathrm{d} \varepsilon
$$

Based on the average toughness calculated from the toughness values given in Table 5, we can say that the toughness-resistance values for Variants 1, 2 and 3 are very similar, while the values obtained for Variants 4,5 , 6 and 7 are higher. The highest roughness value was obtained for Variant 8.

An increase in the toughness of the samples subjected to the holding process in liquid nitrogen amounted only to an average ratio of $6.33 \%$, and an average ratio of $22.76 \%$ was recorded for the samples subjected to the cryogenic process. The most significant reason for this high performance of the CP compared to the HPLN in terms of an increase in the toughness is the fact that the cryogenic process ensures a more stable structure by helping to remove the stresses from the material structure through a linear temperature change. ${ }^{5,16,20}$ On the other hand, for the HPLN, it is not possible to find a fully linear behaviour when the temperature is on a decrease or on an increase back to ambient temperature.

\subsection{XRD analysis}

The patterns obtained through the XRD analyses conducted to investigate the effects of the HPLN and CP

Table 4: Tensile-strenght data (R: raw, HPLN: holding process in liquid nitrogen, CP: cryogenic process, A: austempering, TE: tempering)

\begin{tabular}{|c|c|c|c|c|c|c|c|c|}
\hline \multirow{2}{*}{ Tensile Joule } & $\begin{array}{c}\text { Var 1: } \\
\text { R }\end{array}$ & $\begin{array}{c}\text { Var 2: } \\
\text { HPLN }\end{array}$ & $\begin{array}{c}\text { Var 3: } \\
\text { CP }\end{array}$ & $\begin{array}{c}\text { Var 4: } \\
\text { A }\end{array}$ & $\begin{array}{c}\text { Var 5: } \\
\text { A+HPLN }\end{array}$ & $\begin{array}{c}\text { Var 6: } \\
\text { A+CP }\end{array}$ & $\begin{array}{c}\text { Var 7: } \\
\text { A+HPLN+TE }\end{array}$ & $\begin{array}{c}\text { Var 8: } \\
\text { A+CP+TE }\end{array}$ \\
\hline Average & 1145 & 1137 & 1130 & 1891 & 1885 & 1890 & 1904 \\
\hline
\end{tabular}

Table 5: Toughness data (R: raw, HPLN: holding process in liquid nitrogen, CP: cryogenic process, A: austempering, TE: tempering)

\begin{tabular}{|c|c|c|c|c|c|c|c|c|}
\hline $\begin{array}{l}\text { Toughness } \\
\mathrm{N} / \mathrm{mm}^{2}\end{array}$ & $\begin{array}{c}\text { Var } 1: \\
\mathrm{R}\end{array}$ & $\begin{array}{l}\text { Var 2: } \\
\text { HPLN }\end{array}$ & $\begin{array}{l}\text { Var 3: } \\
\text { CP }\end{array}$ & $\begin{array}{c}\text { Var 4: } \\
\text { A }\end{array}$ & $\begin{array}{c}\text { Var 5: } \\
\text { A+HPLN }\end{array}$ & $\begin{array}{l}\text { Var 6: } \\
\mathrm{A}+\mathrm{CP}\end{array}$ & $\begin{array}{c}\text { Var } 7: \\
\text { A+HPLN+TE }\end{array}$ & $\begin{array}{c}\text { Var 8: } \\
\mathrm{A}+\mathrm{CP}+\mathrm{TE}\end{array}$ \\
\hline Average & 64.165 & 61.943 & 61.007 & 108.015 & 113.403 & 121.714 & 116.312 & 143.476 \\
\hline
\end{tabular}


Table 6: Average particle (crystalite) sizes

\begin{tabular}{|c|c|c|c|c|c|c|c|c|}
\hline & $\begin{array}{c}\text { Var 1: } \\
\mathrm{R}\end{array}$ & $\begin{array}{c}\text { Var 2: } \\
\text { HPLN }\end{array}$ & $\begin{array}{c}\text { Var 3: } \\
\text { CP }\end{array}$ & $\begin{array}{c}\text { Var 4: } \\
\text { A }\end{array}$ & $\begin{array}{c}\text { Var 5: } \\
\text { A +HPLN }\end{array}$ & $\begin{array}{c}\text { Var 6: } \\
\text { A + CP }\end{array}$ & $\begin{array}{c}\text { Var 7: } \\
\text { A+HPL+TE }\end{array}$ & $\begin{array}{c}\text { Var 8: } \\
\text { A+ CP +TE }\end{array}$ \\
\hline $\begin{array}{c}\text { Crystalline } \\
\text { size (nm) }\end{array}$ & 4.391 & 3.948 & 4.066 & 3.729 & 3.550 & 3.357 & 3.090 & 3.085 \\
\hline
\end{tabular}

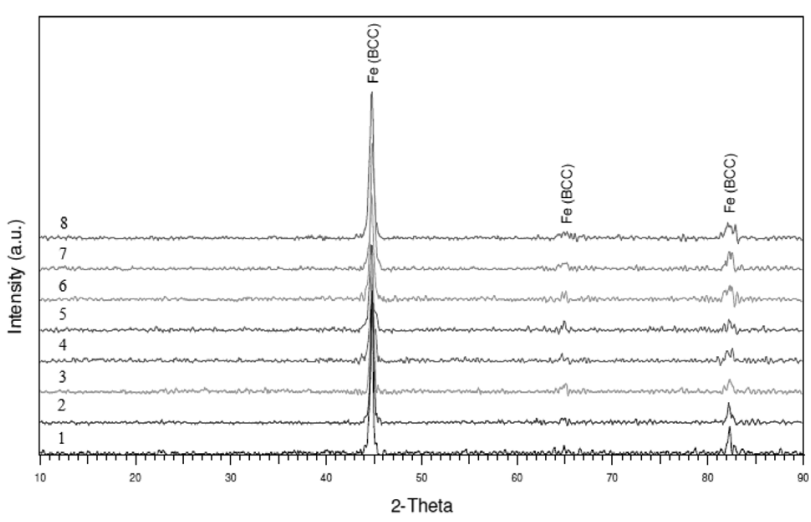

Figure 3: XRD data representing effects of HPLN and CP on SAE 4140 steel

on the SAE 4140 steel are given in Figure 3. The phase of the treated layer was analyzed with XRD, using $\mathrm{Cu}-K_{\alpha}$ radiation. A diffractometer with radiation with a wavelength of $0.15418 \mathrm{~nm}$ having a nickel filter, equipped with an X-ray generator was used. Figure 3 shows the XRDs of the samples evaluated through an X-ray study of diffraction patterns by means of a software database of JCPDS (Joint Committee on Powder Diffraction Standards). The XRD analysis represents almost entirely the a-phase (Fe-BCC).

The crystallite sizes of the prepared samples were calculated using the Scherrer equation (Equation 2) ${ }^{27}$ where $L_{\mathrm{hkl}}$ is the size of crystallite, $\lambda$ is the wavelength of the $\mathrm{x}$-ray source used, $\beta$ is the full width at half maximum (FWHM) of the peaks of the x-ray patterns, and $\theta$ is the peak angle:

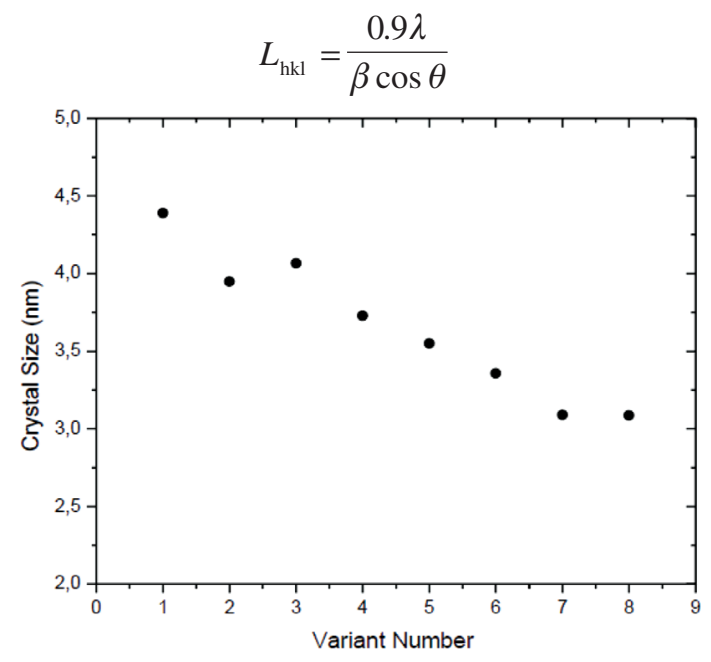

Figure 4: Changes in the crystalline size
Crystallite sizes provide information on the quality of crystallites and are inversely proportional to the full width half maximum of diffraction peaks obtained with XRD. A diffraction peak, being rather narrow, makes the crystallite size bigger and this demonstrates that the crystallite has a quality structure. ${ }^{28}$ When the data from Table 6 and Figure $\mathbf{4}$ is analysed, it is seen that the HPLN and CP applied onto the samples decrease the sizes of the crystallines.

\section{CONCLUSIONS}

As part of the study, effects of the process of holding in liquid nitrogen and conventional cryogenic process on the hardness, tensile strength and toughness of the SAE 4140 steel were analysed and compared to one another. The following findings were obtained:

It was seen that applying only the HPLN and CP on the raw SAE 4140 steel had no effect on the toughness, microhardness and tensile strength of the material.

HPLN and CP processes caused the tensile strength to partially decrease compared to that of the raw material, and the HPLN and CP applied after austempering had the same effect compared to the samples that underwent austempering only. However, when tempering was applied after austempering + HPLN or austempering + $\mathrm{CP}$, it caused the tensile strength to increase. It is thought that the tempering applied as the last process removes the stress from the structure and consequently increases the tensile strength.

Austempering, the CP and HPLN applied after the austempering and tempering processes caused crystalline sizes to decrease (Figure 4). The reason for the increase in the hardness, tensile strength and toughness resistance may also be explained with the decrease in crystalline sizes.

The best performance in terms of tensile strength was found for Variant 8, which underwent austempering + $\mathrm{CP}+$ tempering. This variant was followed by Variant 7 , which underwent austempering + HPLN + tempering.

It is thought that the HPLN and CP cause the average crystalline sizes to decrease; therefore, they cause the force of gravity between the atoms and increase the toughness resistance and tensile strength.

The process of holding in liquid nitrogen drew near to the conventional cryogenic process by:

a) $99.40 \%$ in the concentric performance,

b) $98.49 \%$ in the tensile-strength performance,

c) $27.81 \%$ in the toughness performance,

d) $52.22 \%$ in the hardness performance. 


\section{Acknowledgement}

This research was funded by the Projects of Scientific Investigation Unit of Gazi University (project code 07/2012-55).

\section{REFERENCES}

${ }^{1}$ Ş. Ekinci, A. Akdemir, Effect of applied load on the wear rate of nitrided AISI 4140 steel, Selçuk Teknik Dergi, 10 (2011) 1, 38-52

${ }^{2}$ S. Ulu, H. Aytekin, G. Said, The effect of the heat treatment between $\mathrm{A} 1$ and $\mathrm{A} 3$ in the $\mathrm{Fe}-\mathrm{Fe} 3 \mathrm{c}$ phase diagram on the some mechanical properties of four different steels, Makine Teknolojileri Elektronik Dergisi, 2 (2006), 1-9

${ }^{3}$ Catalog of the MKE special grade steel types, MKE Printing House, Ankara 1978, 5

${ }^{4} \mathrm{G}$. Höke, Comparison of effects of holding in liquid nitrogen and traditional cryogenic processes on mechanical and microstructure properties of SAE 4140 steel, Msc Thesis, Gazi University Graduate School of Natural and Applied Sciences, Ankara,2014

${ }^{5}$ F. K. Arslan, The effect of sub-zero treatment on the mechanical properties of cold work tool steels, Msc Thesis, Sakarya University Graduate School of Natural and Applied Sciences, Sakarya 2010, 82

${ }^{6} \mathrm{E}$. Kesti, Investigation of effects of quenching media on microstructure and mechanical properties of 4140 steel, Msc Thesis, Selçuk University Graduate School of Natural and Applied Sciences, Konya 2009, 14-23

${ }^{7}$ S. H. Avner, Introduction to Physical Metallurgy, McGraw Hill Book Company, 2. Ed., 1986,New York, 315-336

${ }^{8}$ S. Choo, S. Lee, M. G. Golkovski, Effects of accelerated electron beam irradiation on surface hardening and fatigue properties in an Ç-4140 steel used for automotive crankshaft, Materials Science and Engineering A 293, (2000), 56-70

${ }^{9}$ Y. Yildiz, The effects of cold and cryogenically treated copper electrodes and beryllium-copper alloy workpieces on the performance of electro discharge machining, PhD Thesis, Gazi University Graduate School of Natural and Applied Sciences, Ankara 2010, 65

${ }^{10}$ V. Firouzdor, E. Nejati, F. Khomamizadeh, Effect of deep cryogenic treatment on wear resistance and tool life of M2 HSS drill, Journal of Materials Processing Technology, 206 (2008), 467-472, doi:10.1016/ j.jmatprotec.2007.12.072

${ }^{11}$ K. H. W. Seah, M. Rahman, K. H. Yong, Performance evaluation of cryogenically treated tungsten carbide cutting tool inserts, Journal of Engineering Manufacture, 217 (2003), 29-43, doi:10.1243/ 095440503762502260

${ }^{12}$ M. Preciado, P. M. Bravo, J. M. Alegre, Effect of low temperature tempering prior cryogenic treatment on carburized steels, Journal of Materials Processing Technology, 176 (2006), 41-44, doi:10.1016/ j.jmatprotec.2006.01.011

${ }^{13}$ S. Harish, A. Bensely, D. Mohan Lal, A. Rajadurai, G. B. Lenkey, Microstructural study of cryogenically treated En 31 bearing steel,
Journal of Materials Processing Technology, 209 (2009) 7, 3351-3357, doi:10.1016/j.jmatprotec.2008.07.046

${ }^{14}$ S. Zhirafar, A. Rezaeian, M. Pugh, Effect of cryogenic treatment on the mechanical properties of 4340 steel, Journal of Materials Processing Technology, 186 (2007), 298-303, doi:10.1016/j.jmatprotec. 2006.12.046

${ }^{15}$ D. Das, A. K. Dutta, K. K. Ray, Optimization of the duration of cryogenic processing to maximize wear resistance of AISI D2 steel, Cryogenics, 49 (2009), 176-184

${ }^{16}$ P. Baldissera, C. Delprete, Effects of deep cryogenic treatment on static mechanical properties of $18 \mathrm{NiCrMo} 5$ carburized steel, Materials and Design, 30 (2009), 1435-1440, doi:10.1016/j.matdes. 2008.08.015

${ }^{17}$ A. Bensely, D. Senthilkumar, D. Mohan Lal, G. Nagarajan, A. Rajadurai, Effect of cryogenic treatment on tensile behavior of case carburized steel 815M17, Materials Characterization, 58 (2007), 485-491, doi:10.1016/j.matchar.2006.06.019

${ }^{18}$ L. Shyamala, A. Bensely, S. Harish, D. Mohan Lal, G. Nagarajan, K. Junik, A. Rajadurai, Fatigue behaviour and fracture mechanism of cryogenically treated En 353 steel, Materials and Design, 30 (2009), 2955-2962, doi:10.1016/j.matdes.2009.01.003

${ }^{19}$ TS EN ISO 6892-1:2011 Technical product documentation, Metallic materials - tensile tests - part 1: Test method at room temperature, TSE Publications, Ankara

${ }^{20} \mathrm{~T}$. Kivak, Investigation of the effect of cryogenic treatment applied on cutting tools on drillability of Ti-6Al-4V alloy, PhD Thesis, Gazi University, Ankara 2012, 36-39

${ }^{21}$ P. Starke, P. Walther, D. Eifler, New fatigue life calculation method for quenched and tempered steel SAE 4140, Materials Science and Engineering: A, 523 (2009) 1-2, 246-252, doi:10.1016/j.msea. 2009.05.067

${ }^{22}$ S. Sitthipong, P. Towatanab, A. Sitticharoenchaic, C. Meengamd, Abrasive wear behavior of surface hardfacing on propeller shafts AISI 4140 alloy steel, Materials Today: Proceedings, 4 (2017), 1492-1499, doi: 10.1016/j.matpr.2017.01.171

${ }^{23}$ F. K. Arslan, The effect of sub-zero treatment on the mechanical properties of cold work tool steels, Msc Thesis, Sakarya University, Sakarya 2010, 41-53

${ }^{24}$ T. Kivak, Investigation of the effect of cryogenic treatment applied on cutting tools on drillability ti-6Al-4V alloy, PhD Thesis, Gazi University, Ankara 2012, 36-39

${ }^{25}$ P. Baldissera, C. Delprete, Effects of deep cryogenic treatment on static mechanical properties of $18 \mathrm{NiCrMo5}$ carburized steel, Materials and Design, 30 (2009), 1435

${ }^{26}$ A. Sebhi, N. Douib, Wear behavior of a low-alloy (AISI-SAE) 4140 steel after quenching and tempering, Materials Today: Proceedings, 3 (2016), 2841-2852, doi:10.1016/j.matpr.2016.07.003

${ }^{27}$ B. D. Cullity, S. R. Stock, Elements of X-ray Diffraction, $2^{\text {nd }}$ ed., Addison-Wesley 1978

${ }^{28}$ T. Savaskan, Material knowledge and inspection, $5^{\text {th }}$ ed., Karadeniz Technical University Publishing, Trabzon 2009, 49-63 